\title{
Basal cell carcinoma missed by deep shave biopsy: A sampling error
}

\author{
Amir A. Bajoghli, Robert DeAngelis, Alexander O'Campo \\ Department of Medicine (Dermatology), Virginia Commonwealth University, USA
}

Correspondence: Amir A. Bajoghli. Address: Department of Medicine (Dermatology), Virginia Commonwealth University, USA. Email: amirb@me.com

Received: September 16, 2014

Accepted: December 9, 2014 Online Published: December 24, 2014

DOI : $10.5430 /$ jst.v4n4p43

URL: http://dx.doi.org/10.5430/jst.v4n4p43

\begin{abstract}
An 85 year old Caucasian male with no history of immunosuppression presented with an asymptomatic bump on his left lateral neck which was present for several weeks. Physical examination revealed $1.0 \mathrm{~cm} \times 0.8 \mathrm{~cm}$ flesh colored soft nodule associated with an underlying well healed scar on the left lateral neck. He had a nodular basal cell carcinoma (BCC) without any evidence of perineural invasion which was removed by a wide local excision with $4 \mathrm{~mm}$ margins in the area of the scar on the left lateral neck 14 months earlier. The results of that excision had revealed clear surgical margins. The area had healed well post operatively without any complications. Patient requested a biopsy of the bump because he was convinced that the bump represented a recurrence of his BCC. A deep frozen section biopsy of the bump was performed which revealed scar tissue with no evidence of any malignancy. The biopsy tissue from the frozen section was then submitted for permanent section processing in formalin which also showed the same diagnosis of scar tissue with no evidence of malignancy Patient was informed of the results but he insisted on having further resection of the lesion as he was still convinced that the lesion is cancerous. He then underwent a deeper excision of the same area which revealed basal cell carcinoma. Patient subsequently underwent Mohs micrographic surgery for more definitive treatment which required 3 stages. During the first stage of Mohs surgery, the top portion of the slide revealed only scar tissue and positive basal cell margin was at the very deep margin with only a small focus of tumor present. Subsequent Mohs stage revealed larger areas of basal cell carcinoma extending deeper into the neck tissue. This case illustrates that a negative skin biopsy report does not always rule out skin cancer. Clinical judgment and high index of suspicion especially in high risk individuals is essential in making accurate diagnosis of skin cancers. Relying solely on laboratory testing such as a skin biopsy slide alone may not be adequate and further tissue examination maybe necessary in cases of recurrent basal cell carcinoma.
\end{abstract}

\section{Key words}

Basal cell carcinoma, Biopsy, Mohs surgery, Missed tumor, Skin neoplasm, Facial neoplasm, Recurrent tumor

\section{I ntroduction}

The frequency and clinical impact of errors in the anatomic pathology diagnosis of cancer have been poorly characterized. Pathology errors are secondary to misinterpretation or poor clinical sampling of tissues and can result in serious harm to the patient. In this case we present the potential for missing the diagnosis of a recurrent basal cell carcinoma on the neck by solely relying on anatomic pathology results. 


\section{Case presentation}

An 85 year old Caucasian male with no history of immunosuppression presented with an asymptomatic bump on his left lateral neck which was present for several weeks. Physical examination revealed a $1.0 \mathrm{~cm} \times 0.8 \mathrm{~cm}$ flesh colored soft nodule associated with an underlying well healed scar on the left lateral neck. He had a nodular basal cell carcinoma (BCC) without any evidence of perineural invasion which was removed by a wide local excision with $4 \mathrm{~mm}$ margins in the area of the scar on the left lateral neck fourteen months earlier. The results of that excision had revealed clear surgical margins. The area had healed well post operatively without any complications. The leading differential diagnosis of the new bump was a recurrent BCC. A deep frozen section biopsy of the bump was performed which revealed scar tissue with no evidence of any malignancy. The biopsy tissue from the frozen section was then submitted for permanent section processing in formalin which also showed the same diagnosis of scar tissue with no evidence of malignancy (see Figure 1). This "negative" pathological finding did not correlate with the clinical suspicion for the presence of malignancy. The patient's history of prior skin cancers and the physical exam findings of the lesion along with the clinical judgment and acumen of the treating physician led to the decision to excise further tissue despite the "negative" results of the original deep biopsy. Patient was informed of the results immediately and he insisted on having further resection of the lesion as well as he was still convinced that the lesion is cancerous. He then underwent a deeper excision of the same area which revealed basal cell carcinoma (see Figure 2). Patient subsequently underwent Mohs micrographic surgery based on common indications for the procedure such as tumor location, histologic features, and recurrent tumor. Mohs surgery was performed with a $2 \mathrm{~mm}$ margin around the biopsy site for more definitive treatment which required 3 stages. Interestingly, during the first stage of Mohs surgery, the top portion of the slide revealed only scar tissue and positive basal cell margin was at the very deep margin with only a small focus of tumor present (see Figure 3). Subsequent Mohs stage revealed larger areas of basal cell carcinoma extending deeper into the neck tissue.

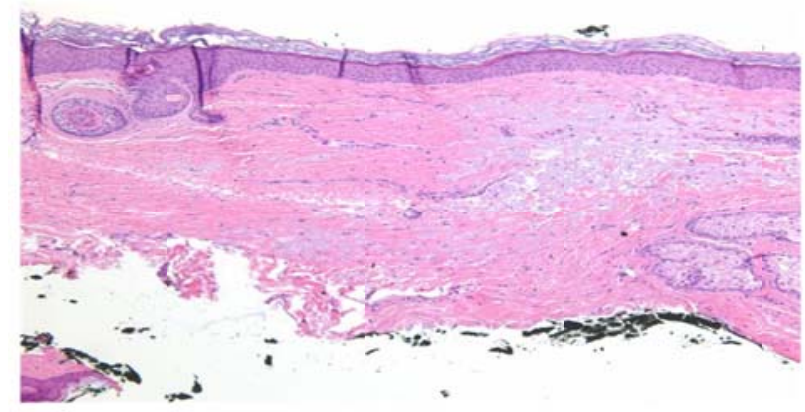

Figure 1. Dermal scar which extends to the base of the specimen (H\&E, 4×). There is no evidence of basal cell carcinoma.
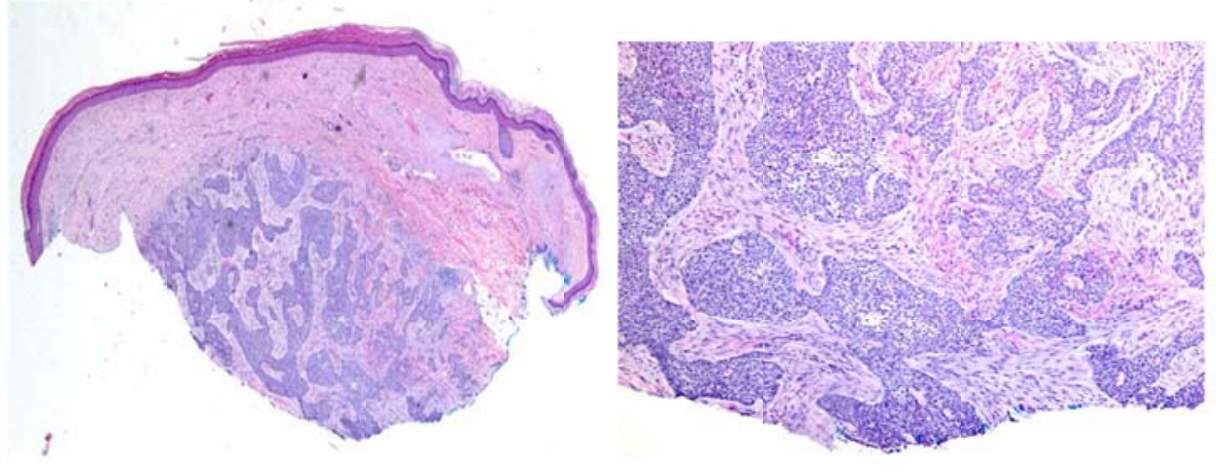

Figure 2. Repeat deep excisional biopsy from the scarred area revealed a deep dermal tumor nodule, composed of irregular strands/nests of basaloid cells with peripheral palisading of nuclei, associated with a fibromyxoid stroma (H\&E, $2 \times$; inset, 20×). 

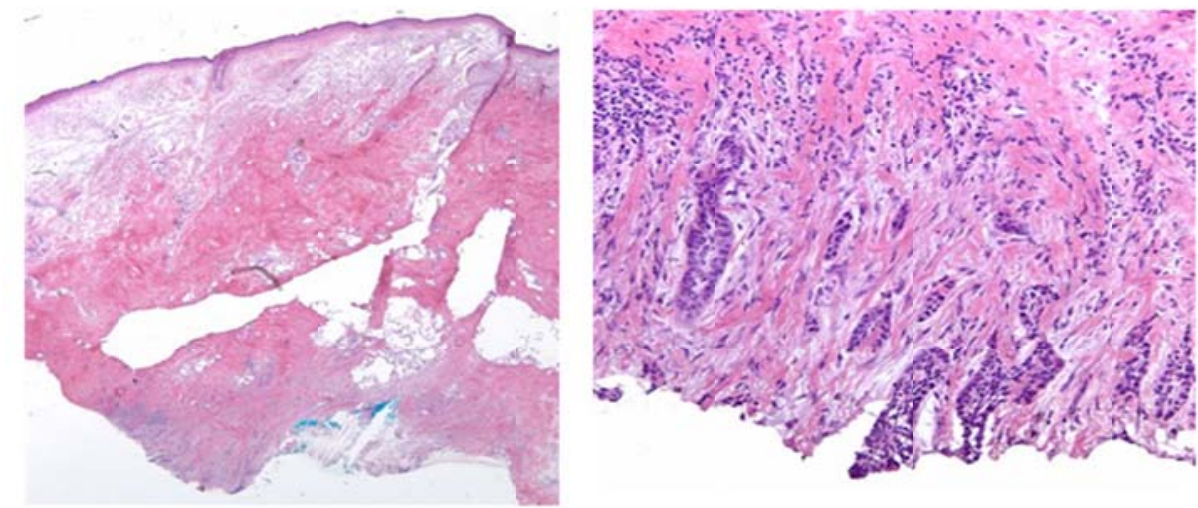

Figure 3. First stage of subsequent Mohs surgery demonstrated mostly scar tissue (H\&E $2 \times)$. There is a small focus of basal cell carcinoma with stromal retraction artifact at the deep margin of the specimen (inset, 20×).

\section{Discussion}

Basal cell carcinoma is the most common malignancy in humans with nearly 2.8 million cases reported in the United States each year ${ }^{[1,2]}$. The diagnosis of basal cell carcinoma is based on the patient history and risk factors, physical exam findings and histological tissue examination. Mohs micrographic surgery offers the highest cure rate while preserving the most amount of normal tissue with minimal surgical complications ${ }^{[3]}$. The procedure has also been shown to be cost effective in treating head and neck cancers ${ }^{[4-8]}$. In a recent multicenter retrospective study of 871 basal cell carcinomas that were biopsied and then removed by Mohs micrographic surgery it was shown that compared with Mohs specimens, biopsy underestimated the diversity of tumor subtypes in $64 \%$ of cases, and underestimated tumor aggressiveness in $24 \%$ of cases. Skin biopsies can be a sub sample of the malignancy and fail to detect all BCC subtypes, and as such may underestimate the aggressiveness of an individual BCC tumor ${ }^{[9]}$. In another recently published article data collection of 1,000 cases of Mohs surgery from a large academic teaching hospital was obtained regarding margins on skin biopsy and compared with margins on the first stage of MMS. Of the biopsies that showed clear margins, a positive margin of cancer was seen in $30 \%$ of the cases on the first stage of Mohs surgery ${ }^{[10]}$. Other published articles have shown that primary BCCs that appear to be completely removed after a biopsy procedure are at risk for recurrence without further treatment ${ }^{[11-13]}$. There are also published studies to show that limited sampling of the skin may be inadequate for an accurate diagnosis of pigmented melanocytic lesions on actinically damaged skin. Areas chosen for biopsy may not contain the most advanced areas histologically and may fail to detect foci of invasive melanoma elsewhere within the lesion. This case illustrates that a negative skin biopsy report does not always rule out skin cancer. In this case, unlike the other recently published and presented data which either underestimated the clinical subtype of the BCC or revealed tumor but with clear margins, the actual cancer cells were missed all together for a BCC. This occurred because the cells were in a deeper portion of the skin than what was sampled initially despite a relatively deep initial biopsy. Clinical judgment and high index of suspicion especially in high risk individuals is essential in making accurate diagnosis of skin cancers. Relying solely on laboratory testing such as a skin biopsy slide alone may not be adequate and further tissue examination maybe necessary in some cases of recurrent basal cell carcinoma ${ }^{[14-16]}$.

\section{References}

[1] Cancer facts and figures. Atlanta: American Cancer Society, 2014.

[2] Rogers HW, Weinstock MA, Harris AR, et al. Incidence estimate of nonmelanoma skin cancer in the United States, 2006. Arch Dermatol. 2010; 146: 283-287. PMid:20231499 http://dx.doi.org/10.1001/archdermatol.2010.19 
[3] Smeets, NW, et al. Mohs' micrographic surgery for treatment of basal cell carcinoma of the face--results of a retrospective study and review of the literature. Br J Dermatol. 2004; 151(1): 141-7. PMid:15270883 http://dx.doi.org/10.1111/j.1365-2133.2004.06047.x

[4] Roenigk R, Ratz J, Bailin P, Wheeland R. Trends in the presentation and treatment of basal cell carcinomas. J Dermatol Surg Oncol. 1986; 12: 860-5. PMid:3734238 http://dx.doi.org/10.1111/j.1524-4725.1986.tb01993.x

[5] Kimyai-Asadi A, Goldberg LH, Peterson SR, et al. The incidence of major complications from Mohs micrographic surgery performed in office-based and hospital-based settings. J Am Acad Dermatol. 2005; 53: 628-34. PMid:16198783 http://dx.doi.org/10.1016/j.jaad.2005.03.023

[6] Tierney EP, Hanke CW. Cost effectiveness of Mohs micrographic surgery: review of the literature. J Drugs Dermatol. 2009; 8(10): 914-22. PMid:19852120

[7] Bialy TL, Whalen J, Veledar E, et al. Mohs micrographic surgery vs. traditional surgical excision: a cost comparison analysis. Arch Dermatol. 2004; 140: 736-42. PMid:15210467 http://dx.doi.org/10.1001/archderm.140.6.736

[8] Cook J, Zitelli J. Mohs micrographic surgery: a cost analysis. J Am Acad Dermatol. 1998; 39: 698-703. http://dx.doi.org/10.1016/S0190-9622(98)70041-6

[9] Murad A, et al. Biopsy can underestimate the diversity, aggressiveness of basal cell carcinomas. Oral Presentation. American Society for Dermatologic Surgery Annual Meeting. San Diego, CA. Nov 2014.

[10] Koslosky CL, et al. Reliability of Skin Biopsies in Determining Accurate Tumor Margins: A Retrospective Study After Mohs Micrographic Surgery. Dermatol Surg. 2014; 40(9): 964-970. PMid:25099294 http://dx.doi.org/10.1097/01.DSS.0000452621.79017.19

[11] Kimyai-Asadi A, Goldberg LH, Jih MH. Accuracy of serial transverse cross-sections in detecting residual basal cell carcinoma at the surgical margins of an elliptical excision specimen. J Am Acad Dermatol. 2005; 53: 469-74. PMid:16112355 http://dx.doi.org/10.1016/j.jaad.2005.02.049

[12] Holmkvist K, Rogers G, Dahl P. Incidence of residual basal cell carcinoma in patients who appear tumor free after biopsy. J Am Acad Dermatol. 1999; 41: 600-5. http://dx.doi.org/10.1016/S0190-9622(99)70305-1

[13] Chuang G, Lu L, Cummins D, Wu H, et al. Incidence of invasive squamous cell carcinomas in biopsy-proven squamous cell carcinomas in situ sent for Mohs micrographic surgery. Dermatol Surg. 2012; 38: 1456-60. PMid:22734860 http://dx.doi.org/10.1111/j.1524-4725.2012.02507.x

[14] Somach SC, Taira JW, Pitha JV, Everett MA. Pigmented lesions in actinically damaged skin. Histopathologic comparison of biopsy and excisional specimens. Arch Dermatol. 1996; 132(11): 1297-302. PMid:8915306 http://dx.doi.org/10.1001/archderm.132.11.1297

[15] Stevens G, Cocherell CJ. Avoiding sampling error in the biopsy of pigmented lesions. Arch Dermatol. 1996; 132(11): 1380-2. http://dx.doi.org/10.1001/archderm.132.11.1380

[16] Jacob J, Austin CA, Slater DN. A negative skin biopsy for malignancy does not exclude the possibility of subsequent fatal disease. Postgrad Med J. 1995; 71(834): 253. PMid:7784299 http://dx.doi.org/10.1136/pgmj.71.834.253-a 